Article

\title{
Collective and Individual Sources of Women's Creativity: Heroism and Psychological Types Involved in Enhancing the Talent of Emerging Leaders
}

\author{
José V. Pestana * and Nuria Codina ${ }^{\circ}$ \\ Department of Social Psychology and Quantitative Psychology, University of Barcelona, Barcelona 08022, Spain; \\ ncodina@ub.edu \\ * Correspondence: jvpestana@ub.edu; Tel.: +34-93-3125176
}

Received: 30 April 2020; Accepted: 27 May 2020; Published: 28 May 2020

check for updates

\begin{abstract}
In heroism, leadership research has a myth that provides the basis for a deeper exploration of the characteristics of the unconscious (collective, personal) and consciousness of leaders-characteristics that can mobilize their followers. This contribution goes on to show that heroism can provide a foundation that foments the creativity of women leaders-from a sustainable standpoint-with the purpose of jointly analyzing aspects of the collective unconscious (heroism), the personal unconscious (psychological typology), and consciousness (self-descriptions, values) in a sample of women emerging as leaders. The participants in the study were 34 students following a Master's program oriented towards training future CEOs as leaders, aged between 22 and 38 years old $(M=27.22$ years old; $S D=3.77)$. The instruments consisted of a story that each participant wrote about herself as the main heroine; the Myers-Briggs Type Indicator (MBTI); the Twenty-Statement Test (TST); and a questionnaire on personal values. The main results show the common structure of the stories of personal heroism, as well as the characteristics (unconscious, conscious, personal, and collective) that can serve to foster the sustainable use of personal creativity. The research carried out provides knowledge that may be integrated into other perspectives of leadership analysis.
\end{abstract}

Keywords: creativity; heroism; Jungian psychology; leadership; Myers-Briggs Type Indicator; social psychology; Twenty-Statement Test; values; women

\section{Introduction}

This research is based on the premise of heroism as a myth that can foster the creative talent of women leaders, which contributes positively to sustainable training in leadership. It draws on the perspective of analytical psychology developed by C. G. Jung. This approach to leadership-in our opinion, as revealing as it is scarcely documented-can complement and broaden the scope of the main trends in the study of leaders and followers, as well as the studies on creativity in women and sustainable education. As described in the following sections, most approaches to leadership have laid the emphasis - unilaterally - on the individual or situational variables of this process. Only recently have proposals emerged that integrate and transcend both types of variables-and in this respect, they opt for a style of leadership that also points to sustainable practices in human resource management.

In this paper, we argue in favor of the innovative character that Jungian analytical psychology contributes to the analysis of leadership. Specifically, elements of the collective unconscious (heroism), the individual unconscious (psychological typology), and consciousness (self-descriptions, values) are considered in conjunction. We draw on this line of thought to show how our approach can help in a sustainable way to enhance the talent of emerging women leaders with regard to their creativity. 
Based on these ideas, the arguments that underpin this research are presented below. First, the main characteristics of the evolution of leadership studies are discussed: From a leader-centered vision to the conception of leadership as a process in which both leaders and followers are the main actors. This is followed by a description of the conception of heroism as a perspective that articulates and deepens the personal, interpersonal, and collective aspects of leadership. This introduction then ends with a line of reasoning that defends the role played by heroism in the sustainable promotion of creativity in women as emerging leaders.

\subsection{Leadership, from Charisma to Prototypicality}

Before presenting the differential contribution of analytical psychology in the study of the promotion of creativity in emerging women leaders, it is necessary to delimit the concept of leadership, briefly pointing out the scope and limits of the main approaches in the psychosocial study of leadership, and attending to their possibilities regarding sustainable organizational practices.

Leadership is a basic psychosocial process that, expressed simply, enables others to do something. For Hogg [1] (p. 1166): "Leaders are agents of influence. When people are influenced it is often because of effective leadership. Influence and leadership are thus tightly intertwined". Thus, research on leadership implies, among other things, uncovering the evidence about what mobilizes individuals. In this respect, three trends in leadership research can be distinguished [2]: Great men and the cult of personality; the context and contingency/transaction/transformation; and social identity/social categorization. By and large, the two first perspectives have gradually calibrated the explanatory potential of the individual and the social in leadership, i.e., with the goal of identifying the most decisive factor in the leadership process. With the perspective related to the social identity/social categorization, both factors are integrated, which has opened new ways for equally integrative explanations-as well as alternatives-to these three perspectives in leadership research.

Great men and the cult of personality. The main attribute of this perspective is charisma, with Weber [3] (p. 245) being considered the classic reference: "The natural leaders in distress have been holders of specific gifts of the body and spirit; and these gifts have been believed to be supernatural, not accessible to everybody". Therefore, this conception of leadership assumes that it is those special attributes of leaders (generally men) that result in them being followed by the masses. Over time, this perspective, with its focus on charisma, has included research that in one way or another recurs to personality as a fundamental explanation of the whys and wherefores of leadership [4-7]. Specifically, the personality of leaders has been described as characterized predominantly by extraversion, conscientiousness, and openness to experience [5].

This assumption that leadership is a phenomenon that mainly depends on the leader's personality has been the subject of criticism, the most common argument being the scant or zero importance given to social and/or historical contexts. By way of an example, it is enough to imagine what would happen if any leader from other time was now at the head of a community. This criticism does not ignore the impact on a group made by the personal characteristics of the person who leads it, as in the case, for example, of the harm done by seductive narcissistic leaders to their followers [8]. In their most negative version, seductive narcissists present themselves as saviors who can make up for the deficiencies of the others, who throw in their support out of apathy and inactivity.

The context: Contingency, transaction, transformation. In the pioneering studies on leadership styles led by K. Lewin $[9,10]$, it was demonstrated empirically that the same group of children behaved differently under autocratic, democratic, and laissez-faire leaders. This malleability in the face of changing circumstances laid the foundations of an approach to leadership studies that prioritizes the importance of the environment in explaining this process. Within this line of research, the work done by Fiedler [11] deserves particular attention, where he conceived leadership as the product of the possible contingencies existing between the context variables related to leader-member relations, task structure, and position power. For Fiedler [11] (p. 184), "the training of leaders [would consist] in diagnosing their group-task situation and in adopting strategies which capitalize on their particular 
leadership style" - in other words, in observing the combination of variables and acting accordingly (for a recent review of this model, see [12]). Another major contribution to this perspective but laying the stress on the leader-follower relationship, is made by the concept of transformational leadership [13]. This integrates previous contributions while distinguishing three styles: Charismatic (characterized by a rare combination of exceptional individuals and circumstances); transactional (which prioritizes the mere exchange of rewards between leader and followers); and transformational in the strict sense of the term, where leaders "point to mutual interests with followers. They engage followers closely without using power, using moral leadership. They transform individuals, groups, organizations, and societies" [13] (p. 873). A recent review of the contributions made by this model in [14].

An important transition can be observed in this approach to leadership research. From prioritizing the mere circumstances surrounding leaders and followers, it moved on to highlight what happens between the influencing individual and those who are influenced-a link that has been described as invisible [15]. Nonetheless, this approach, with its emphasis on the interactive fact of leadership-either with the context or with people-encounters its main challenges in the why and how of the influence of leaders; respectively, the component of interaction that explains why leaders and followers exist, and the principle that underlies the interinfluence between leader and followers. This leadership, based on interinfluences, not only takes into account the context and the people in specific situations, but also integrates interinfluence and the value of sustainability [16,17], i.e., in a practice that, over time, is sensitive to the demands of the moment, without incurring standards or provisions that do not meet the needs of leaders and followers.

The social identity/social categorization approach. The combination of the theories of social identity (proposed by H. Tajfel) and self-categorization (with J.C. Turner as the main advocate) has engendered another approach to the issue of leadership. To be precise, its proponents have drawn on the two theories to conceive leadership as a process in which it is fundamental to belong to a group (the "we" or in-group) and feel that such belonging is key to our self-perception. In this regard, effective leadership follows these four principles [2]: (1) Being one of us (leaders as the best representatives of the corresponding in-group prototypes); (2) doing it for us (leaders as in-group champions, i.e., being the main persons responsible for promoting the interests of the group); (3) crafting a sense of us (leaders as entrepreneurs of identity, i.e., actively working on the definition - and redefinition - of their own prototypicality); and (4) making us matter (leaders as embedders of identity, doing so through specific actions that distinguish the group from other ones-in the present and in the future). This conception of leadership, which counts on the respective empirical support [18,19], assumes that the prototypicality of any leader does not respond to immanent, rigid categories, but to the process that the said leader and his/her followers experience.

With the introduction of the prototype as a definition of leadership within an in-group, this approach to the analysis of leadership has integrated the individual and the situational in terms of the interinfluences between leaders and followers-without overlooking their transience: Who is a leader today may not be tomorrow. To this integration should be added an analysis of what, in the key of the individual and the collective unconscious, may stimulate the interinfluences of the leadership process at a given moment.

\subsection{Heroism in Leadership: From the Collective Myth to the Psychological Typology of the Leader}

In the three perspectives followed by leadership studies, there appears to be a tendency towards the integration of the individual and the social, as occurs in the case of prototypicality and in-group. However, this integration demands deeper analysis—and Jungian analytical psychology provides a promising perspective in this respect. This experience of integration is also related to the impact that is sought after with the promotion of sustainable leadership, which has one of its main goals in holistic personal growth and development [20].

With the goal of introducing this perspective into the study of leadership, this section describes the main concepts of Jungian analytical psychology: First, the collective unconscious-highlighting 
the myth of heroism; then, the personal unconscious and consciousness (Figure 1); and finally, the psychological types as constructs that allow the observation of the transit between the unconscious and consciousness. This description is intended to highlight the importance of integrating the leader's unconscious (collective, personal) and conscious content, given that integration is crucial to fostering creativity in leadership-in women in the case in question.

The collective unconscious. This includes the main content "universal and of regular occurrence" [21] (\$270) transmitted by myths across human history; myths that constitute an opportunity to give voice to figures (known as archetypes), conflicts, and the concerns of individuals. By way of an example of this extant ancient content, let us imagine that a woman has been listening to her partner explaining problems in his/her job. She repeatedly warns him/her to be careful because something bad could happen to him/her. Later, her partner explains with surprise that a conflict has emerged at work. The woman says, "I warned you." Her partner replies, "About what?" (Much to her bewilderment—or considerable annoyance, as the case may be). This everyday situation exemplifies a modern version of the myth of Cassandra, an archetypal figure $\left(\mathrm{A}_{\mathrm{C}}\right.$, Figure 1$)$ fated to be clairvoyant without anyone paying her any attention or believing her-in fact, her premonitions about the Trojan War were ignored. Also, it is possible that the woman's experience (E, idem Figure 1) in our example makes her aware of the relevance of the content of the collective unconscious for her individual psyche.

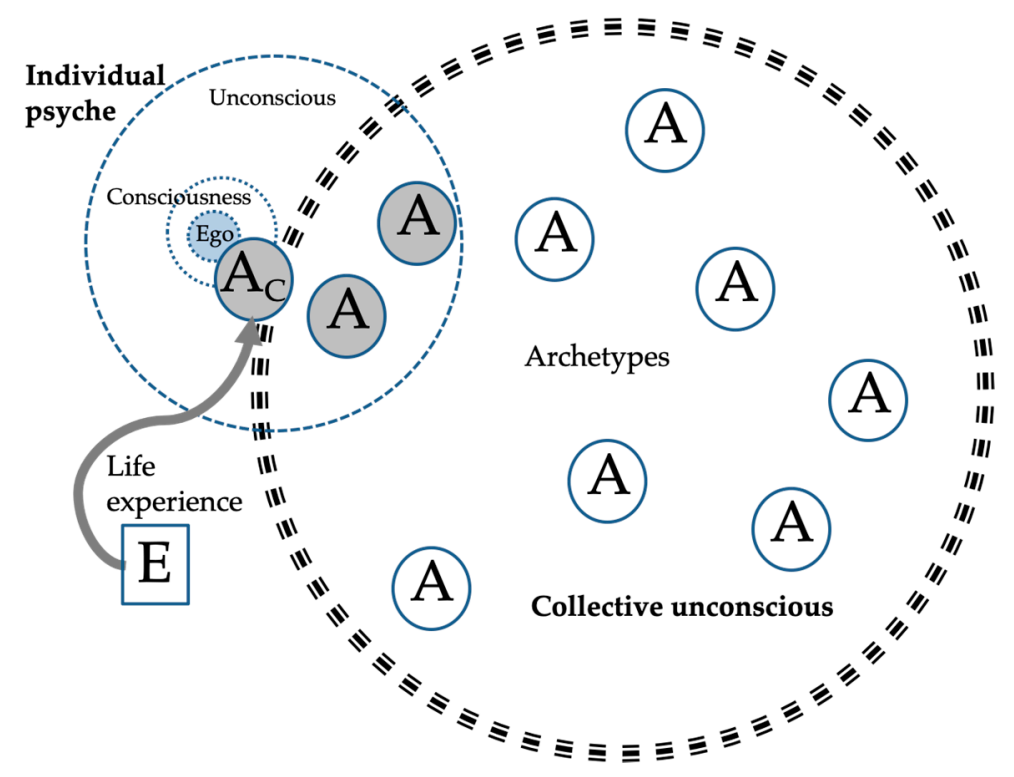

Figure 1. Relationships between the collective unconscious and the individual psyche (explanation in the text). Source: Prepared by the authors according to [21,22].

A common component of all myths is heroism, i.e., the presence of an archetypal figure-hero or heroine-whose extraordinary powers and adventures reveal important content for groups and individuals. For Jung [23] (\$68) the figure of the hero/heroine is the "symbolical exponent of the movement of libido". In other words, just as each individual has a physical structure-which favors putting some abilities or others into practice-there is also a certain amount of psychic energy or libido waiting to be discovered and fostered. For Jung [24] (\$612), moreover, "The hero myth is an unconscious drama seen only in projection." In other words, it is the content that individuals show of themselves and address to others. Therefore, the foundations for the transformation of the leader will be laid so far as the leader becomes aware of the heroic imaginary: "Further transformations run true to the hero myth" [21] (\$303). What is the consequence of this assertion? That on knowing the archetypal figures that most move a leader, the keys to what mobilizes the followers can be visualized. The description of the good-enough leader [25] (p. 40) expresses this idea: A person who, aware of his/her limitations, can recognize himself/herself in figures such as the erotic leader (who "brings out and 
reflects back the healthy self-love and self-admiration that exists in everyone"), the trickster-as-leader (fostering an attraction to his/her visionary ideas), and the sibling leader (establishing alliances through decentralization and shared work in networks).

A woman leader might feel akin, for example, to the Wonder Woman heroine [26,27]. Fighting with aggressors to protect the weak, thanks to values such as strength and truthfulness, as well as having the power to deflect attacks by her enemies (such as the bracelets on her clothes, which deflect bullets). As a figure in popular culture, this update of the myth of the archetypal figure of the Amazon has gradually incorporated details from the imaginary of the different times that have elapsed since its appearance $[28,29]$.

On the other hand, apart from the archetypal figures and myths known to the general population, it is necessary to identify the myths appearing in the individual psyche-with its own unconscious and conscious content.

The individual unconscious/consciousness and psychological types. This part of the individual psyche includes all the forgotten content (and which is repressed in some cases) derived from each individual's experiences [23]. In contrast with the unconscious, the consciousness-with the ego at the center-is made up of everything we remember and that our psyche makes use of in everyday life [30]. The differences between the unconscious and the consciousness do not imply a division between the two. On the contrary: On the one hand, unconscious content can pass into consciousness-through dreams (while we are asleep) and fantasies (while awake); and on the other hand, what happens in the conscious mind can impact the unconscious-for example, a gesture from someone that has attracted our attention can be amplified in dreams, clarifying our idea of the other person's intentions towards us.

Finally, apart from the fantasy content, another way to access the exchange of psychic energy between the unconsciousness and consciousness is through the psychological types [31]. The main feature of this classification is the differentiation between introversion and extraversion. Each of these orientations of psychic energy can be present in the world of consciousness (being observed by those around us) or remain in the unconscious (i.e., expressing themselves indirectly).

With respect to the extraverted conscious attitude, the "orientation by the object predominates in such a way that decisions and actions are determined not by subjective views but by objective conditions" [31], §563. Thus, an extravert leader will make financial decisions based on recent data offered by the market or the sales of competitors. By contrast, the extraverted unconscious attitude includes subjective impulses that go unrecognized-and are accepted with difficulty in the conscious mind (for example, not admitting unpleasant behavior when negotiating with someone who, deep down, we view as someone dishonest).

In the case of conscious introversion, the individual "is naturally aware of external conditions, [but] selects the subjective determinants as the decisive ones... Whereas the extravert continually appeals to what comes to him from the object, the introvert relies principally on what the sense impression constellates in the subject" [31] (\$621). In this sense, an example would be the introverted leader who makes decisions based on his/her subjective impressions of reality-and which those around may not share. With regards to the introverted unconscious attitude, this is characterized by an intensification of the object: This would be the case of the leader who, with far greater conviction and resolve than the rest, insists on carrying out a certain strategy—which she assumes to be something totally objective (which ultimately it is not).

Jung [31] drew on this extraversion-introversion theory to propose the existence of four psychological functions, two rational ones (thinking, feeling) and two irrational ones (sensation, intuition):

- Thinking (T), which "following its own laws, brings the contents of ideation into conceptual connection with one another" [31] (\$830). This would be the case of someone who, when deciding what furniture to buy for the office, is guided by rational arguments (objective or objectifiable: Quality, ergonomics, and price). 
- Feeling (F) includes two processes: On the one hand, attributing to an object "a definite value in the sense of acceptance or rejection ('like' or 'dislike')"; on the other hand, experiencing a mood that also implies "a valuation; not of one definite, individual conscious content, but of the whole conscious situation at the moment, and, once again, with special reference to the question of acceptance or rejection" [31] (\$724). An example of the predominance of this function would be the leader who chooses the furniture according to what she feels is right and wrong in its design (traditional or avant-garde, unobtrusive or conspicuous, etc.).

- Sensation (perception, S), without being held to the laws of reason, "mediates the perception of a physical stimulus ... [and] is related not only to external stimuli but to inner ones, i.e., to changes in the internal organic processes" [31] (\$792). Here, an example would be a reaction to the furniture where the purely aesthetic side prevails, linked to aspects such as color or form (experienced as ideal or horrible, for example-whatever the case, expressed in terms that could be described as exaggerated).

- Finally, intuition (I), which "mediates perceptions in an unconscious way. Everything, whether outer or inner objects or their relationships, can be the focus of this perception ... In intuition a content presents itself whole and complete, without our being able to explain or discover how this content came into existence" [31] (\$770) (original italics). In this case, our leader would introduce the subject by saying, for example, that in the morning-while having breakfast- the complete picture of how to transform the space and the way it would look had sprung to mind.

This typology has been measured with the Myers-Briggs Type Indicator [32]. This scale offers data on polarities related to introversion-extraversion, thinking-feeling, and sensation-intuition. Depending on the person's degree of consciousness of each of these functions, they are considered primary, auxiliary, tertiary, and inferior functions. Moreover, the MBTI incorporates judging (J) and perceiving $(\mathrm{P})$ as attitudes for facing the outside world. The combinations of these aspects result in a total of 16 profiles that can vary throughout life, with their comprehension leading to better self-understanding [33,34]. In this study-and in line with the proposals in [35] —we also considered the concept of value in relation to the levels of consciousness of the four psychological functions, thereby complementing the information provided by the MBTI. As representations that respond to needs transformed into goals [36], values guide human actions [37], being sensitive to historical and cultural aspects. The importance of values has been shown in the case of leadership [38-42] —and specifically with regards to their relationship with leaders' psychological typology and conception of heroism [43].

To sum up, this description of the concepts involved in analytical psychology informs us of the possibility of taking into account aspects of the unconscious (collective, personal) and consciousness of leaders, through their vision of heroism and the corresponding psychological typology in conjunction with its value orientation. Thus, this approach goes beyond considerations about leadership based on Freudian-type psychoanalysis of the personalities of leaders and followers [44]. The analytical psychology perspective makes it possible to complement any conception of the interinfluence between leader and members, which in sustainable leadership, is crucial to its "processes of connecting people, things and places; rather than being about a person or organizational position" [45] (p. 1072). In the case at hand and as far as leaders are concerned, this is achieved by assuming that the personal characteristics they reveal integrate the personal and the collective-without having to choose between the variables of the individual or the situation when studying leadership.

Furthermore, this integrated approach has the potential to reveal the keys to what mobilizes a group under the influence of its leader. Consequently, we assume that there is much deeper content underlying the prototypicality that unites an in-group, which on becoming conscious, may offer a new source of energy that is conducive to creative leadership. Finally, it should be noted that the proposed integration of content is akin to the conception of sustainable leadership where the leader must have a long-term transdisciplinary vision [46]. 


\subsection{The Role of Heroism in Fomenting Creativity in Women Leaders from a Sustainable Perspective}

In heroism, leadership research has a myth that provides the basis for a deeper exploration of the characteristics of unconscious (collective, personal) and consciousness of leaders-characteristics that can mobilize their followers. This paper goes on to show that heroism can provide a foundation that foments the creativity of women leaders, a conception that is also based on an applied vision of sustainability, i.e., going beyond ecological practices or activism in favor of environmental conservation [47]. The development of this idea draws on previous evidence about heroism and the main obstacles observed in enhancing creativity and leadership in women-also connecting with the aspiration of an approach and leadership training that sustainably enhances the talent of women [48].

As an explanation of leaders' behavior, the study of the role of heroism reveals that the individual basis for what is considered heroic encompasses a series of specific features (categories, prototypes, self-representations) [49-51]. Heroes have also been known to fulfill a series of functions that can be a powerful social influence for other individuals [52-54] — and, specifically, in the relationships between leader and followers $[55,56]$. Moreover, the function of heroism in leadership is consistent with contributions linked to the idea of heroism as a tool for providing guidelines that influence the way individuals may lead their own lives [57-60].

However, the question remains: Once a leader becomes aware of the heroic figure that he/she is mobilized by, how can this experience be translated into creativity? According to the precepts of analytical psychology [61], the answer lies in activating those archetypal images that, even though they come from antiquity, personify present-day conflicts, and suggest possible solutions not previously contemplated. Therefore, transcendent creativity would ensue as a consequence of this experience, according to which the most important thing for the individual is "to give voice, to announce something beyond himself, something transcendent" [62] (p. 14). Thus, the connection with the content of the collective unconscious, which anyone can draw on at any given moment, constitutes an important step towards contact with creative material [63]—in the way of artists (with regards to the importance of interdisciplinarity in fostering creativity, see [64]). The phenomena of collective creativity may be observed in addition to this transcendent creativity-which consists of being able to predict a formula for success in a group of individuals. On the other hand, the type of creativity that facilitates self-expression and self-development in individuals-without much involvement of other people-remains on a more personal level $[62,65,66]$. This conception of analytical psychology is linked to and expands the definition of creativity [67]: "The ability to perceive new relationships, and to derive new ideas and solve problems by pursuing non-traditional patterns of thinking".

Research on creativity has to take into account both the so-called intraindividual components and the external components (those provided by the social context [68]). Here, a paradox has been observed [69]. On the one hand, the benefits of creativity in individuals have been demonstrated, but on the other hand, since creativity implies innovation, it may meet with resistance from conventional positions. This dual circumstance is particularly evident in studies on creativity and women. In this sense, research on the characteristics of creative women has highlighted, among other aspects, the capacity of the imagination and an originality that is not exempt from a certain rebellion against conventions [70-74]. All told, the exercise of creativity in women has encountered a lack of support in their surroundings $[75,76]$.

As far as women's leadership is concerned, the research carried out highlights the coexistence of two realities. On the one hand, there is a greater presence of women as leaders in various sectors of society [77-79]. On the other hand, the obstacles that society itself puts in the way-more or less implicitly_of women's leadership make it difficult to consolidate and place on an equal footing with men's leadership [80]. As a strategy to cope with this situation, the importance of authenticity has been highlighted [81], which suggests a preparation that favors the empowerment of leadership in women [82,83], with special emphasis on their creativity: "In order for the force of women's leadership to continually build momentum in dominant organizational cultures, women leaders must be able to 
fully, rather than just strategically, engage in their unique, feminine, creative, and innate approaches to leadership" [80] (p. 21).

According to the above, the new ideas and non-traditional patterns of relationships could be transferred to women's leadership, on women becoming aware of the characteristics derived from the collective unconscious that make up their own heroism [84]. Through this consciousness, women emerging as leaders would have a basis to develop new ways of articulating their individuality in relation to the group. In addition, this articulation would offer an alternative to the previous corpus of scientific knowledge, which has reported the difficulties involved in advancing women's creativity and leadership.

Lastly, it must be highlighted that the approach adopted here appeals to the unique, innovative qualities that women as leaders are able to contribute in favor of sustainability [85]; i.e., it is optimal management that caters to the individual and the group both in the present and with a view to the future [86]. Specifically, the comprehensive self-knowledge proposed by this research shares three principles of sustainable education [87]. To be precise, being able to articulate one's own imaginary of heroism in practice favors integrative thinking and practice; attending to the implications that one's own heroism has in the present and the future works in favor of envisioning change; and the foundations for achieving transformation are laid by making conscious the guidelines for personal and collective change. In short, the fact that women as emerging leaders experience personal and collective content (conscious and unconscious) entails experiencing dimensions of sustainable learning such as awareness of their own professional skills [88], as well as the empowerment for life of the already available modes of reasoning and expression [89].

\section{Method}

This research was non-experimental, associative, and cross-sectional [90]. In this sense, the observed relationship between the variables was geared towards valuing the proposed theoretical model, i.e., heroism - with its individual and collective variables—as a basis for nurturing creativity in women leaders.

\subsection{Participants}

The participants were a non-probability purposive sample of 34 women aged between 22 and 38 years old $(M=27.22$ years old; $S D=3.77)$, who were studying in a Master's program oriented towards training future CEOs as leaders. Participation in the study was voluntary. The completion of the questionnaires had no bearing on course grades.

\subsection{Instruments}

Data were collected using four instruments: A questionnaire where each participant told a story in which she was the main heroine; the Myers-Briggs Type Indicator; the Twenty-Statement Test; and the Personal Values questionnaire. The questionnaires were applied in the order shown below, organized according to the need for greater or lesser elaboration on the part of the participants, this being related to the gradual sequencing demanded by the self-observation process when combining instruments with qualitative and quantitative data [91,92].

\subsubsection{Story about one's Own Heroine}

This questionnaire consisted of writing a story in which the respondent was the protagonist ("heroine") [43]. The respondents were asked to include a beginning, a development (rising and falling action), and an end (denouement). However, they were free to take as much time as they wished and use any extra space they needed for writing, and choose the subject and the degree of realism of the story, in order to obtain an approximation to the degree to which heroism could be articulated-with a greater or lesser degree of consciousness-into the life narratives [93]. In this respect, the heroine could, for example, have special powers or have her adventures in different eras or contexts. This tool 
addresses the importance of story-writing in training for sustainability: "its intentional usage can now be traced in practices which attempt to transform how we relate to each other, the planet, and its co-inhabitants, and often in the context of inculcating well-being to combat the consequences of modern life" [94] (p. 1538).

The stories were analyzed according to the characteristics regarding the three parts of the hero/heroine adventure [95]: Departure (The call to adventure, Refusal of the call, Supernatural aid, The crossing of the first threshold, The belly of the whale); Initiation (The road of Trials, The meeting with the goddess, Woman as the temptress, Atonement with the father, Apotheosis, The ultimate Boon); and Return (Refusal of the return, The magic flight, Rescue from without, The crossing of the return, Threshold, Master of the two worlds, Freedom to live). For each core part of the participant's story, its predominant characteristics were identified. For example: If the part corresponding to the Departure gives more weight to the Refusal of the call, this characteristic was awarded a frequency of 1 (and so on for the other two core parts of the story-Initiation and Return). Table 1 summarizes the contents of the core parts and their characteristics.

Table 1. Contents of the heroine story [95].

\begin{tabular}{|c|c|}
\hline \multicolumn{2}{|l|}{ Departure } \\
\hline The Call to Adventure & Appearance of a mystery that must be solved. \\
\hline Refusal of the Call & $\begin{array}{l}\text { Difficulties in giving up one's own interests when faced with } \\
\text { the mission to be fulfilled. }\end{array}$ \\
\hline Supernatural Aid & $\begin{array}{l}\text { Appearance of a protector figure (and his/her lucky charms, } \\
\text { amulets) to help at the beginning of the mission. }\end{array}$ \\
\hline The Crossing of the First Threshold & First step taken within the sacred area. \\
\hline The Belly of the Whale & Staying in the sphere of rebirth or metamorphosis. \\
\hline \multicolumn{2}{|l|}{ Initiation } \\
\hline The Road of Trials & Facing difficulties. \\
\hline The Meeting with the Goddess & $\begin{array}{c}\text { Appearance of a presence that announces everything that can } \\
\text { be known about the mission. }\end{array}$ \\
\hline Woman as the Temptress & $\begin{array}{l}\text { Appearance of a presence that can interfere with the mission to } \\
\text { be carried out. }\end{array}$ \\
\hline Atonement with the Father & $\begin{array}{l}\text { Having a transcendent vision after accepting what is } \\
\text { one's own. }\end{array}$ \\
\hline Apotheosis & Divine state after overcoming ignorance. \\
\hline The Ultimate Boon & Adventure that the chosen one carries out with ease. \\
\hline \multicolumn{2}{|l|}{ Return } \\
\hline Refusal of the Return & Rejection of returning with the trophy won. \\
\hline The Magic Flight & Flight with miraculous obstacles. \\
\hline Rescue from Without & Call from the Society to re-join it. \\
\hline The Crossing of the Return Threshold & First step taken in starting the return trip. \\
\hline Master of the Two Worlds & $\begin{array}{l}\text { Transition between the world or dimensions of the universe } \\
\text { known before and during the mission. }\end{array}$ \\
\hline Freedom to Live & $\begin{array}{l}\text { Reconciliation between the individual conscience and the } \\
\text { universal will, that is, integrating the achievements of the } \\
\text { mission in the original context. }\end{array}$ \\
\hline
\end{tabular}

\subsubsection{Myers-Briggs Type Indicator (MBTI)}

The questionnaire used was the Spanish version of the MBTI in form G, with 126 items (117 items with two response options, and the other nine with three) and based on the test specifying psychological typology developed by C. G. Jung [32]. The instrument presents a total of 16 profiles that can vary throughout life, with their comprehension leading to better self-understanding [33,34]. The MBTI also considers the distinction between extraversion -introversion and the four functions of the psyche [31]: Thinking (T), feeling (F), sensation (S), and intuition $(\mathrm{N})$. Depending on the person's degree of consciousness of each of these functions, they are considered primary, auxiliary, tertiary, and inferior 
functions. The suitability and validity of the MBTI have been documented recently in studies that have used it to analyze leader profiles [96,97] and student typologies [98].

In this study, the information obtained was analyzed according to: The prevalence of the 16 psychological types; the four axes (or main characteristics) on which these types are organized (focusing the attention/extraversion-introversion, making decisions/thinking-feeling, orientation toward the outer world/judging-perceiving, and taking in information/sensation-intuition), and the degree of consciousness of each of these functions: Primary (dominant or favorite attitude), auxiliary (balancing the dominant attitude), tertiary (opposite to the auxiliary), and inferior (opposite to the dominant)—determined by the scores obtained from the items of the inventory and the relationships of complementarity and opposition among the functions themselves [32].

\subsubsection{Twenty-Statement Test}

The Twenty-Statement Test (TST) [99] in its original form consisted of responding 20 times-i.e., 20 self-descriptions or self-definitions-to the question "Who am I?". This test offers the possibility of free expression without relinquishing the systematization of structured instruments [100,101]. Recently, the validity of this test has been demonstrated in research carried out in different contexts [102-105]. Likewise, the TST facilitates access to the sense of self, a requirement for the active learning that comes with introducing sustainability issues into higher education [106,107].

The categorization of self-descriptions was accomplished by following the criteria covering the attitudinal categories, as established by Escobar et al. [104]. By drawing on the analysis carried out by Kuhn and McPartland [99] on the subjective meaning of the self-definitions that people provide about themselves, these authors established 10 attitudinal categories (each with examples from the participants in this study): (1) Self-evaluations, through which individuals express their way of being in the light of six possible dimensions-1.1 intellectual aptitudes (competencies that are not directly observable: "Intelligent and very capable"), 1.2 practical aptitudes (observable behavioral competencies: "Ability to work under pressure"), 1.3 character and morals (self-reflections: "Values of honesty and responsibility"), 1.4 social life (relational characteristics: "I easily become attached to people"), 1.5 aesthetics (appreciations about what is attractive: "I place a lot of importance on physical appearance, both in myself and in others"), and 1.6 emotional outlook (state of mind: "Enthusiastic when dealing with uncertainty"); (2) self-esteem, where people express their degree of satisfaction with themselves ("I accept myself as I am"); (3) preferences, description of personal tastes ("I like trying new things"); (4) beliefs, expression of opinions about reality ("Perseverance is the key to success"); and (5) ambitions, statements regarding their own future ("Always looking ahead to the future").

\subsubsection{Personal Values Questionnaire}

This questionnaire is the Spanish adaptation of the Schwartz Value Survey [108] developed by Abella, Lezcano, and Casado ([109]; after [110]). This version consists of 50 items where each participant has to "rate the importance of each value item as a guiding principle in their life" [109] (p. 238). The items in the questionnaire refer to the following 10 values (five items per value, with an example in each case): tradition ("devout"), security ("social order"), stimulation ("varied life"), conformity ("obedient"), hedonism ("enjoying life"), achievement ("ambitious"), benevolence ("helpful"), power ("authority"), self-direction ("choosing own goals"), and universalism ("unity with nature"). Each item can be scored from 1 ("I have it very little or not at all") to 7 ("I have it a lot or to a high degree").

The score for each value was obtained by adding up the points from the five items, yielding a range between 5 (in the case of giving the lowest score to the five value items) and 35 points (if all five items were given a score of seven).

\subsection{Procedure}

Before collecting data, we contacted the academic office of the university whose students would take part in the sample. After obtaining the corresponding authorization to use the aforesaid instruments 
as a part of the research, the students were allowed to continue participating only if they agreed to sign the informed consent. The ethical requirements of the University of Barcelona Bioethics Commission (CBUB, Institutional Review Board IRB00003099) were applied to the current study, which meant that additional approval for the research was not required because the data obtained did not involve animal or clinical experimentation. Additionally, this study complies with the recommendations of the General Council of Spanish Psychological Associations (Consejo General de Colegios de Psicólogos), the Spanish Organic Law on Data Protection [111], and the Declaration of Helsinki [112].

Data collection was carried out face-to-face, under the supervision of researchers from the team who have experience in the application of the instruments used. Data collection was carried out on paper in the first semester of the 2018/2019 academic year during daytime hours before class time-in order to avoid interfering with the Master's degree classes attended by the participants. It was organized into four sessions (one per instrument). Data collection ended before the final examinations, in order to avoid the biases that may emerge when collecting information during the semester evaluation period.

\subsection{Statistical Analysis}

The data obtained were processed using version 25 of the SPSS program, as described below.

The prevalence is indicated (i.e., the number $n$ of participants out of the total of $N=34$ ) in the case of the stories about their own heroine, the psychological typology (the types derived from the MBTI and their basic characteristics), and the self-descriptions. With regards to these self-descriptions, the mean $(M)$ and standard deviation $(S D)$ of self-descriptions by category were also calculated for the whole sample. As to the values, we show their $M$ and $S D$.

The Chi square coefficient between the categories of stories, psychological types, and self-descriptions was used to establish the associations between data. When these variables were combined with the scores for the values, Student's $t$ coefficient was used. In each case, the corresponding size effect was calculated: In the case of the Chi square coefficient, by means of Cramer's $V$; and in the case of $t$, with Cohen's $d$.

\section{Results}

\subsection{Stories about the Own Heroine}

With regard to the stories told by the participants, in which they were the main heroines (Table 2), there was a predominant tendency in each part of the story. Specifically, departure was mainly characterized by the call of adventure $(n=20,58.8 \%)$, initiation by the road of trials $(n=19,55.9 \%)$, and return by freedom to live $(n=23,67.6 \%)$.

To illustrate these predominant tendencies in each part of the stories, we present the following examples (the additional text is intended to situate the reader in the context of the story, while the part that illustrates the corresponding tendency is highlighted in italics):

- The Call of Adventure/Departure

"I remembered someone I hadn't seen for a long time. I began to wonder: How is she? What's she doing? But only for a moment. Then, just before I fell asleep, I received a message. The sender was precisely the person I had been thinking about a little earlier! I was surprised-we hadn't spoken to each other for months. I waited a little while before opening the message. When I did, I read: 'Hello, sorry to bother you so late at night, but you're the only one who can help me!"”

- Initiation/The Road of Trials

"One day, the little princess found herself face to face with the toughest challenge in her life, and in her family's life as well ... She was confronted by situations that she never thought she would have to cope with—and her family neither ... During this time, the little princess had to abandon her fairy tale existence." 
- Return/Freedom to Live

“... Person A [name not given] had accomplished her mission and it was time to join the peoples of the world who needed her help."

Table 2. Percentage of participants according to the main tendencies in each part of the heroine story $(N=34)$.

\begin{tabular}{ccc}
\hline Departure & $n$ & $\%$ \\
\hline The Call to Adventure & 20 & 58.8 \\
Refusal of the Call & 5 & 14.7 \\
Supernatural Aid & 4 & 11.8 \\
The Crossing of the First Threshold & 1 & 2.9 \\
The Belly of the Whale & 1 & 2.9 \\
N/A & 3 & 8.8 \\
\hline Initiation & & \\
\hline The Road of Trials & 19 & 55.9 \\
Theeting with the Goddess & 3 & 8.8 \\
Woman as the Temptress & 1 & 2.9 \\
Atonement with the Father & 2 & 5.9 \\
Apotheosis & 6 & 17.6 \\
The Ultimate Boon & 0 & - \\
N/A & 3 & 8.8 \\
\hline Return & & \\
\hline Refusal of the Return & 1 & 2.9 \\
The Magic Flight & 0 & - \\
Rescue from Without & 0 & - \\
The Crosing of the Return Threshold & 3 & 8.8 \\
Master of the Two Worlds & 4 & 11.8 \\
Freedom to Live & 23 & 67.6 \\
N/A & 3 & 8.8 \\
\hline
\end{tabular}

Given the tendencies found in each part of the stories, we went on to dichotomize the categories as follows: In departure, the call of adventure/other departures $(f=20,58.8 \% / f=11,32.4 \%)$; in initiation, the road of trials/other initiations $(f=19,55.9 \% / f=12,35.3 \%)$; and in return, freedom to live/other returns $(f=23,67.6 \% / f=8,23.5 \%)$. Thanks to this re-categorization it was possible to observe significant associations between the content of the heroine stories, the basic characteristics of the psychological types, the self-descriptions, and the predominant values of the participants.

\subsection{Psychological Types}

The analysis of the psychological types (Table 3) revealed the predominance of two types over the others: The ISTJ profile (introverted sensation with extraverted thinking: $n=15$, representing $44.1 \%$ of the sample) and the ESTJ profile (extraverted thinking with introverted sensation: $n=8$, equivalent to $23.5 \%$ of the participants). Both profiles share sensation and thinking as dominant and auxiliary functions. In the case of the ISTJ profile, sensation is the dominant function, and thinking is auxiliary-while the opposite occurs with the ESTJ profile. This same relationship is observed in the tertiary and lower functions (respectively feeling and intuition) of ISTJ and ESTJ-with the latter in reverse order. It can be observed that the main trait differentiating these profiles is that the focus of attention of ISTJ is introverted, whereas it is extraverted in the case of the ESTJ.

With regards to the types observed, the prevalence of the functions of the psychological types according to the degree of consciousness of each of the functions (primary, auxiliary, tertiary, and inferior) was as follows (Table 4): Sensation was the most frequent primary function and thinking predominated 
as an auxiliary function. Feeling was the tertiary function with the highest proportion of participants and intuition was relegated to the position of main inferior function.

Table 3. Percentage of participants according to their psychological types $(N=34)$.

\begin{tabular}{ccc}
\hline Psychological Types & $\boldsymbol{n}$ & $\%$ \\
\hline ISTJ/Introverted Sensation with Extraverted Thinking & 15 & 44.1 \\
ISFJ/Introverted Sensation with Extraverted Feeling & 0 & - \\
ESTP /Extraverted Sensation with Introverted Thinking & 1 & 2.9 \\
ESFP /Extraverted Sensation with Introverted Feeling & 2 & 5.9 \\
INTJ/Introverted Intuition with Extraverted Thinking & 0 & - \\
INFJ/Introverted Intuition with Extraverted Feeling & 0 & - \\
ENTP/Extraverted Intuition with Introverted Thinking & 2 & 5.9 \\
ENFP/Extraverted Intuition with Introverted Feeling & 0 & - \\
ISTP/Introverted Thinking with Extraverted Sensing & 2 & 5.9 \\
INTP/Introverted Thinking with Extraverted Intuition & 0 & - \\
ESTJ/Extraverted Thinking with Introverted Sensing & 8 & 23.5 \\
ENTJ/Extraverted Thinking with Introverted Intuition & 2 & 5.9 \\
ISFP/Introverted Feeling with Extraverted Sensing & 0 & - \\
INFP/Introverted Feeling with Extraverted Intuition & 0 & - \\
ESFJ /Extraverted Feeling with Introverted Sensing & 2 & 5.9 \\
ENFJ/Extraverted Feeling with Introverted Intuition & 0 & - \\
\hline
\end{tabular}

Table 4. Percentage of participants according to degree of consciousness of each of the functions $(N=34)$.

\begin{tabular}{ccccccccc}
\hline \multirow{2}{*}{ Functions } & \multicolumn{2}{c}{ Primary } & \multicolumn{2}{c}{ Auxiliary } & \multicolumn{2}{c}{ Tertiary } & \multicolumn{2}{c}{ Inferior } \\
\cline { 2 - 9 } & $\boldsymbol{n}$ & $\boldsymbol{\%}$ & $\boldsymbol{n}$ & $\boldsymbol{\%}$ & $\boldsymbol{n}$ & $\boldsymbol{\%}$ & $\boldsymbol{n}$ & $\boldsymbol{\%}$ \\
\hline Thinking & 12 & 35.3 & 18 & 52.9 & 2 & 5.9 & 2 & 5.9 \\
Feeling & 2 & 5.9 & 2 & 5.9 & 18 & 52.9 & 12 & 35.3 \\
Sensation & 18 & 52.9 & 12 & 35.3 & 2 & 5.9 & 2 & 5.9 \\
Intuition & 2 & 5.9 & 2 & 5.9 & 12 & 35.3 & 18 & 52.9 \\
\hline
\end{tabular}

Lastly, the consideration of the psychological types according to their four main basic characteristics (Table 5) revealed the symmetrical distribution of the sample with respect to focusing the attention (given that one half is extraverted and the other is introverted). Among the rest of the characteristics, the highest frequencies were as follow: In making decisions, thinking $(n=30,88.2 \%)$; in facing the outer world, judging $(n=27,79.4 \%)$; and in taking in information, sensation $(n=30,88.2 \%$, with one case where the two functions obtained exactly the same scores).

Table 5. Percentage of participants according to the basic characteristics of the types $(N=34)$.

\begin{tabular}{ccc}
\hline Focusing the Attention & $n$ & $\%$ \\
\hline Extraversion & 17 & 50.0 \\
Introversion & 17 & 50.0 \\
\hline Making decisions & \\
\hline Thinking & 30 & 88.2 \\
Feeling & 4 & 11.8 \\
\hline Orienting toward the & \\
outer world & & \\
\hline Judging & 27 & 79.4 \\
Perceiving & 7 & 20.6 \\
\hline Taking in information & & \\
\hline Sensation & 30 & 88.2 \\
Intuition & 3 & 8.8 \\
Sensation \& Intuition & 1 & 2.9 \\
\hline
\end{tabular}


These basic characteristics of the psychological types displayed significant associations with some aspects of the heroine story; specifically, in the way of taking in information. Thus, those who met the characteristic of intuition started their stories in a different way to the others (typified by the call of adventure, showing a strong association: $\chi^{2}=8.35, p=0.015, V=0.519$ ).

\subsection{Self-Descriptions}

The categories used to classified the self-descriptions provided two data items (Table 6): On the one hand, the number of participants in whose responses the categories were observed; and, on the other hand, the mean of self-descriptions by category in the sample as a whole. In this way, it was possible to find out not only how many cases a category appeared in, but also in what numbers.

Thus, among the 10 categories used to classify self-descriptions, self-evaluations of character/morals and social life were the most present-in $88.8 \%$ of the sample in both cases. Among the rest, the category of preferences stands out, appearing in the self-descriptions of $67.6 \%$ of the sample. When observing the mean of self-descriptions by category, again character/morals stands out above the rest $(M=6.55$; $S D=3.27$ ), making it not only one of the most prevalent categories in the sample, but also the one that, on average, received the most mentions.

Table 6. Prevalence, means, and standard deviations for the categories of self-descriptions $(N=34)$.

\begin{tabular}{ccccc}
\hline Categories & $\boldsymbol{n}$ & $\mathbf{\%}$ & $\boldsymbol{M}$ & $\boldsymbol{S D}$ \\
\hline Self-evaluations & & & & \\
\hline Intellectual aptitudes & 12 & 35.3 & 0.42 & 0.56 \\
Practical aptitudes & 20 & 58.8 & 1.97 & 2.04 \\
Character and morals & 30 & 88.8 & 6.55 & 3.27 \\
Social life & 30 & 88.8 & 3.74 & 2.35 \\
Aesthetics & 1 & 2.9 & 0.03 & 0.18 \\
Emotional outlook & 11 & 32.4 & 0.45 & 0.67 \\
\hline Self-esteem & 9 & 26.5 & 0.35 & 0.60 \\
\hline Preferences & 23 & 67.6 & 2.58 & 2.51 \\
\hline Beliefs & 16 & 47.1 & 2.90 & 5.11 \\
\hline Ambitions & 9 & 26.5 & 0.48 & 1.15 \\
\hline
\end{tabular}

In addition, the presence of these categories of self-descriptions was associated with the structure of the heroine story and the degree of consciousness of each of the functions (information not tabulated).

In the categories of the self-descriptions, that of ambitions (despite only appearing in $26.5 \%$ of the participants) was strongly associated with the type of departure described. Specifically, most of those who referred to their future expectations in their self-descriptions began their story in a different way to the majority $\left(\chi^{2}=5.98, p=0.014, V=0.454\right)$.

With regards to the functions of psychological typology, the category of preferences was strongly present among those who had sensation and thinking as an auxiliary function and intuition and feeling as a tertiary function $\left(\chi^{2}=7.97, p=0.047, V=0.507\right)$. The category of ambitions was strongly associated with those who have thinking as an auxiliary function and feeling as a tertiary function $\left(\chi^{2}=8.38\right.$, $p=0.039, V=0.520$ ).

As to the mean of self-descriptions by category, it was observed that, when there was a greater number of self-descriptions relative to beliefs, the characteristics of thinking $(t=3.23, p=0.003, d=1.73)$ and judging ( $t=2.92, p=0.007, d=1.56)$ predominated. Likewise, the number of self-descriptions referring to intellectual aptitudes $(t=4.00, p=0.000, d=2.43)$ and self-esteem $(t=3.32, p=0.003$, $d=2.02$ ) was higher among those where the function of sensation predominated. 


\subsection{Values}

Regarding values (Table 7), the highest scores were observed for benevolence $(M=30.83, S D=3.29)$, conformity $(M=29.67, S D=2.55)$, self-direction $(M=28.87, S D=3.12)$, and hedonism $(M=28.46$, $S D=3.42)$. By contrast, the values with the lowest scores were power $(M=24.43, S D=3.79)$, tradition $(M=26.23, S D=3.20)$, and stimulation $(M=26.33, S D=4.20)$.

An emphasis on certain values was also observed according to the main characteristics of the heroine stories, the psychological types, and the self-descriptions.

With regards to the content of the heroine stories, concluding the narrative with a different ending to the majority (Freedom to live) was linked to the values of conformity $(t=-2.36, p=0.026, \mathrm{~d}=1.07$ ), benevolence $(t=-2.45, p=0.023, d=1.07)$, and self-direction $(t=-2.16, p=0.044, d=0.94)$. As to the characteristics of the psychological typology, those who displayed the function of intuition had higher scores in hedonism $(t=-2.64, p=0.032, d=1.93)$ and power $(t=5.24, p=0.000, d=3.84)$.

Finally, those who presented self-descriptions referring to future aspirations-ambitions-displayed greater hedonism $(t=2.31, p=0.030, d=0.97)$, achievement $(t=2.85, p=0.010, d=1.20)$, self-direction $(t=3.75, p=0.001, d=1.58)$, and universalism $(t=2.64, p=0.015, d=1.11)$.

\subsection{Summary of the Main Results}

When considering the main research results as a whole, the following observations can be made:

- The heroine stories can be divided into two different types: On the one hand, an imaginary common to the majority; and on the other hand, a narrative that indicates different ways of approaching heroism. This differentiation is a relevant event, since it is associated with the following factors: The way in which information is taken in from the environment-as a characteristic of psychological types; having ambitions as part of self-descriptions; and taking more into account values such as benevolence and self-direction.

- Regarding the psychological typology, sensation as the primary function, thinking as secondary, feeling as tertiary, and intuition as inferior tend to predominate in the sample as a whole. Furthermore, it is the auxiliary and tertiary functions-i.e., the ones that are not so visible in behavior-that are associated with self-descriptions related to preferences and ambitions. As to the basic characteristics of the types, the ways in which decisions are made and information is taken in are significantly associated with the rest of the variables studied.

- Among the self-descriptions, the category of ambitions stands out in particular-statements regarding the own future, given the aforesaid associations with the rational psychological functions (thinking, feeling) and with 4 of the 10 values studied: Hedonism, achievement, self-direction, and universalism.

- Finally, in the case of values, it is worth mentioning that hedonism is associated with irrational psychological functions (sensation, intuition) and thinking about the future as part of self-descriptions. Another value that should be highlighted is self-direction, which is more evident in those stories of heroism that differ from the majority, in addition to the aforesaid association with the category of ambitions relative to self-descriptions 
Table 7. Means, standard deviations, and associations for the values $(N=34)$

\begin{tabular}{|c|c|c|c|c|c|c|c|c|c|c|c|c|c|c|c|c|c|c|c|c|c|c|c|c|c|}
\hline \multirow{3}{*}{ Values } & \multirow{2}{*}{\multicolumn{2}{|c|}{$\begin{array}{l}\text { General } \\
\text { Sample }\end{array}$}} & \multicolumn{7}{|c|}{ Heroine Story/Return } & \multicolumn{9}{|c|}{ Characteristics of the Types/Taking in Information } & \multicolumn{7}{|c|}{ Self-Descriptions/Ambitions } \\
\hline & & & \multicolumn{2}{|c|}{$\begin{array}{l}\text { Freedom to } \\
\text { Live }\end{array}$} & \multicolumn{2}{|c|}{$\begin{array}{l}\text { Other } \\
\text { Returns }\end{array}$} & \multirow[t]{2}{*}{$t$} & \multirow[t]{2}{*}{$p$} & \multirow[t]{2}{*}{$d$} & \multicolumn{2}{|c|}{ Sensation } & \multicolumn{2}{|c|}{ Intuition } & \multicolumn{2}{|c|}{$\begin{array}{l}\text { Sensation \& } \\
\text { Intuition * }\end{array}$} & \multirow[t]{2}{*}{$t$} & \multirow[t]{2}{*}{$p$} & \multirow[t]{2}{*}{$d$} & \multicolumn{2}{|c|}{ Yes } & \multicolumn{2}{|c|}{ No } & \multirow[t]{2}{*}{$t$} & \multirow[t]{2}{*}{$p$} & \multirow[t]{2}{*}{$d$} \\
\hline & $M$ & $S D$ & $M$ & $S D$ & $M$ & $S D$ & & & & $M$ & $S D$ & $M$ & $S D$ & $M$ & $S D$ & & & & $M$ & $S D$ & $M$ & $S D$ & & & \\
\hline Tradition & 26.23 & 3.20 & 26.60 & 2.96 & 24.71 & 3.90 & 1.33 & 0.194 & - & 26.07 & 3.33 & 27.50 & 0.70 & 28.00 & - & -1.75 & 0.128 & - & 27.13 & 4.39 & 25.89 & 2.78 & 0.88 & 0.387 & - \\
\hline Security & 27.73 & 3.45 & 28.05 & 3.91 & 27.14 & 2.67 & 0.67 & 0.507 & - & 27.63 & 3.58 & 29.00 & 2.82 & 28.00 & - & -0.52 & 0.604 & - & 29.13 & 3.09 & 27.32 & 3.51 & 1.33 & 0.203 & - \\
\hline Stimulation & 26.33 & 4.20 & 26.10 & 4.56 & 27.14 & 2.85 & -0.70 & 0.492 & - & 26.07 & 4.34 & 29.00 & 1.41 & 28.00 & - & -2.24 & 0.116 & - & 28.38 & 2.32 & 25.74 & 4.48 & 2.00 & 0.057 & - \\
\hline Conformity & 29.67 & 2.55 & 29.15 & 2.90 & 31.00 & 1.15 & -2.36 & 0.026 & 1.07 & 29.63 & 2.67 & 30.50 & 0.70 & 29.00 & - & -1.21 & 0.291 & - & 30.75 & 1.58 & 29.37 & 2.91 & 1.58 & 0.126 & - \\
\hline Hedonism & 28.47 & 3.42 & 28.45 & 3.48 & 28.00 & 4.12 & 0.28 & 0.781 & - & 28.26 & 3.54 & 30.50 & 0.70 & 30.00 & - & -2.64 & 0.032 & 1.93 & 30.38 & 2.20 & 27.68 & 3.77 & -2.64 & 0.032 & 1.93 \\
\hline Achievement & 27.47 & 3.56 & 27.25 & 3.75 & 29.00 & 2.51 & -1.19 & 0.253 & - & 27.07 & 3.47 & 32.00 & 2.82 & 29.00 & - & -1.94 & 0.062 & - & 29.88 & 2.47 & 26.42 & 3.64 & 2.85 & 0.010 & 1.20 \\
\hline Benevolence & 30.83 & 3.29 & 30.05 & 3.64 & 32.71 & 1.89 & -2.45 & 0.023 & 1.07 & 30.78 & 3.42 & 32.50 & 0.70 & 29.00 & - & -2.08 & 0.078 & - & 31.88 & 1.80 & 30.47 & 3.93 & 1.26 & 0.217 & - \\
\hline Power & 24.43 & 3.79 & 24.25 & 4.17 & 24.43 & 3.59 & -0.10 & 0.921 & & 24.11 & 3.85 & 28.00 & 0.00 & 26.00 & - & -5.24 & 0.000 & 3.84 & 26.13 & 3.98 & 23.53 & 3.82 & 1.59 & 0.123 & . \\
\hline Self-direction & 28.87 & 3.12 & 28.35 & 3.43 & 30.71 & 2.05 & -2.16 & 0.044 & 0.94 & 28.63 & 3.20 & 30.50 & 0.70 & 32.00 & - & -2.35 & 0.058 & - & 31.13 & 0.99 & 27.89 & 3.43 & 3.75 & 0.001 & 1.58 \\
\hline Universalism & 27.20 & 3.65 & 26.50 & 3.99 & 29.00 & 2.51 & -1.91 & 0.072 & - & 27.04 & 3.72 & 27.00 & 1.41 & 32.00 & - & 0.03 & 0.978 & - & 29.50 & 2.20 & 26.47 & 3.65 & 2.64 & 0.015 & 1.11 \\
\hline
\end{tabular}

Note. With regards to the heroine story, charate shown. Cohen's $d$ was only calculated in the cases with a $p<0.050 .{ }^{*}$ Variable not included in the comparison of means, given its $n=1$ 


\section{Discussion}

This study of heroism in women emerging as leaders, in which the collective unconscious (the heroine myth), the individual unconscious (psychological typology), and consciousness (self-descriptions, values) were jointly analyzed, enabled us to identify the keys that the participants could use to develop their creativity. This brought to light the potential impact on leadership of research and intervention carried out from the perspective of Jungian analytical psychology-where "Leaders are at the same time individuals, representatives of a group, and expressions of a collective unconscious phenomenon" [113] (p. 38). In fact, to the extent that this articulation and integration is fostered between the different levels of the psychosocial leadership process, the guidelines for the sustainable management of training and performance become clear, especially for women $[85,114]$.

\subsection{The Heroine and Her Journey}

The stories, in which the participants were situated as the protagonists, constitute an exercise in which the imagination opens the door to the content of the collective unconscious [23], which would mobilize emerging leaders and their potential followers. In this regard, the general tone of the stories analyzed was a call to action after which they faced difficulties in fulfilling the mission that emerged [95]. Here, the conception of the heroine myth emerges as a way of solving problems-and, by extension, for the followers dependent on this way of proceeding. With regards to the significant associations between the stories and the rest of the variables analyzed, these were observed mainly in cases where the stories unfurled in a different way to the majority. In particular, they were observed among the participants who were most aware of their intuition and defined themselves in terms of their own future.

Promoting the emergence of new ideas-apparently irrational and in prospective terms-emerges as a strategy for fostering creativity in women emerging as leaders, based on the myth of the heroine. [21,52,84]. Then again, contact with one's own heroism should not be confused with fantasies of omnipotence-which, for example, a seductive narcissist may harbor [8]. Becoming aware of which archetypal figures influence one's relationship with others brings with it an active involvement in the perception of images from the unconscious-specifically, in the way they can complement or anticipate consciousness. Consequently, the perspective on heroism taken by analytical psychology can contribute to the understanding of the identity phenomena between leaders and their followers [2]. Given this joint vision, prototypicality is susceptible to reappraisal as that cognition, in the unconscious (collective, personal), may provide additional keys to how it functions.

\subsection{The Psychological Typology, from Consciousness to the Unconscious (and Vice Versa)}

The clarification of which psychic functions are more or less present in the conscious mind [31] reveals which abilities need consolidating and highlighting. With the predominance of sensation as a primary function (i.e., more integrated into consciousness), we have emerging leaders who prioritize what they perceive of what surrounds them-this being associated with self-description in terms of preferences. The counterpart to this perceptual acuity is the situation of intuition as a generally inferior function (more situated in the unconscious), for which reason it is worth reiterating the importance of intervention to favor novel ways of thinking about personal reality [67].

The use of psychological typology in leadership research goes beyond the mere classification of an individual in a certain category. The need to compensate or complement a given type is a work process for each leader-working on themselves and in relation to others. The most frequent psychological type in the sample studied, ISTJ (introverted sensation with extraverted thinking) can be taken as an example:

"ISTJs will give any amount of help if they can see that it is needed, but their logic rebels against requirements or expectation to do anything that doesn't make sense to them. Usually they have difficulty understanding needs that differ widely from their own. But once they are 
convinced that something matters a great deal to a given person, the need becomes a fact worthy of respect" [115] (p. 104)

In this case, it is observed how women, who display this psychological type at some point, must actively work to understand and accept the needs of the other, which in terms of the leader, can lead to a strengthening of the relations with her followers.

\subsection{Self-Descriptions and Values, Beyond Consciousness}

With the introduction of self-descriptions, it was possible to observe the main characteristics of emerging leaders—such as character/morals and social life. Regarding the significant associations-both regarding frequency and the mean of the self-descriptions-they inform us of the relationships between this content and both psychological typology (the more personal aspect) and values (the more collective aspect). Specifically, in the case of psychological typology these associations show, for example, that self-description in terms of ambitions is consistent with the function of feeling (which is usually tertiary, i.e., far below the threshold of consciousness); and in the case of values, they make it clear that this collective representation that guides actions [37] is also consistent with self-perception in terms of the time to come-another point that confirms the importance of shaping leaders' perspectives about a sustainable future.

The interstitial position of self-descriptions with respect to psychological typology and values shows that some answers to the question "Who am I?" are related to the deeper dynamics of the psyche and the values-i.e., they are collective representations that can guide actions towards concrete goals (those of women as emerging leaders in the case at hand). Specifying which self-descriptions have the greatest explanatory potential, for how leaders view themselves, provides information that guides the leadership process towards efficient, long-term goals—ultimately, sustainable ones.

\subsection{Methodology Used and Its Potential to Foster Sustainability}

The results confirm the suitability of the combination of instruments used $[32,99,110]$. Thanks to the story about the inner heroine-an expressive writing activity with the potential for deep and experiential learning [116] — we are able to differentiate not only the stories that introduce the most creative ingredients from a set, but also the articulation between this imaginary of the collective unconscious and the contents of the personal unconscious. The MBTI functions as a valid instrument in leadership research $[43,96,97]$ because it reveals the current exchange of psychic energy in the individual and, in parallel, shows which aspects should be worked on in the future.

The combination of instruments used in this research constitutes an important contribution to the corpus of scientific knowledge because, although they have been validated separately in various studies [104,109], they have rarely been used together (an exception in [43]). This contribution is further enhanced by the fact that this methodology has not often been seen in empirical research based on analytical psychology, and also, above all, because of the fact of instrumentalizing this perspective, thereby enabling it to dialogue with other more consolidated approaches to leadership research. In this sense, for example, the prototypicality of leaders $[2,18,19]$ — which has a cognitive base, also characteristic of questionnaires such as the TST and the Personal Values survey-may display components of interinfluence between leader and followers that should be taken into account both in the spheres of heroism [49-56] and psychological typology [31].

Other aspects of the methodology that should be taken into account are the profile of the participants and the context in which the research was developed: Women who were higher education students in a Master's program oriented towards training future CEOs as leaders. This circumstance makes the acquisition of deep learning possible [117] by offering self-knowledge that understands leadership as a process whose roots lie in the deepest layers of the psyche and that are also likely to spread to the higher-order cognitive skills needed to bring about processes of change [118]. In other words, the study methodology, by bringing to light the person's own resources-urging them to look deeper into themselves-adheres to the parameters of sustainable education in favor of women's leadership. 


\subsection{Limitations and Future Research}

The limitations of this study—such as the nature and size of the sample—also suggest possible paths to initiate new research on heroism in leadership from the perspective of analytical psychology. Although we focused our research on women as emerging leaders, this does not mean we ignore the fact that this reality is affected by gender inequalities and tensions [85]; rather, our findings are an invitation to go deeper into the joint analysis of men and women (collectively, individually, unconsciously, and consciously), a line of research supported by promising incipient evidence [43].

This research focused on the transit between the unconsciousness and consciousness, attending to the collective and the personal. By definition, these concepts have dynamics and transience as their main characteristics-which can make non-experimental, associative, and cross-sectional research look like a snapshot of something in constant motion.

Given these limitations, it is reasonable to think of interventions that introduce causality and experimentation-together with the corresponding statistical analyses that go beyond the descriptive or correlational, like those used in this research. In this sense, it is suggested that future research takes psychosocial interventions as references-and also the corresponding follow-up [44]. This research strategy would demonstrate whether the deep learning and professional skills acquired are sustainable and generalizable - as has been observed in other research on teaching-learning processes in higher education based on sustainability [119-121]. This new approach to the subject under study would also favor the mobilization of psychic content, which apart from permitting a generalization of our findings, ultimately invokes the solution of scientific problems through non-traditional patterns-the essence of creativity itself and the cornerstone of sustainable leadership.

\section{Conclusions}

The inclusion of the myth of heroism in the analysis of the emerging leadership of women constitutes a relevant contribution in that it reveals areas where creativity is contained and therefore shows where it is possible to promote sustainable education, all of which creates a reference framework for future contributions-both theoretical and practical-that will enrich the existing body of scientific knowledge.

By integrating the personal and the collective, the consciousness and the unconscious-as empirically demonstrated in this research-analytical psychology surpasses and complements the unilateral nature of the main trends in the study of leadership: Those that usually emphasize individual or social variables, focusing on the conscious aspects of the psyche. Specifically, this integration between the personal and the collective was verified by the link between the heroic image itself and the psychological typology (which includes different degrees of consciousness), along with conscious content such as the conscious self-image and preferences about the values of the community.

As far as the methodology is concerned, it is worth noting that the sequential application of the instruments used provides a research strategy that, in addition to offering significant data regarding the leadership of women, favors the integration of images from the unconscious in the consciousness. Thus, in a more practical sense, it enables women as emerging leaders to become aware of themselves (personally and collectively) and reveals an authentic content that precedes-and is a condition for-creativity. That is to say, sustainable resources are used on the basis of an education sensitive to sustainability. Consequently, the process that begins with the articulation of the personal imaginary of heroism favors integrative thinking in practice, the envisagement of change, and transformation-three principles of sustainable education that offer women as emerging leaders the possibility of transcending themselves.

Author Contributions: Conceptualization, J.V.P.; methodology, N.C.; investigation, J.V.P.; data curation, J.V.P.; writing-original draft, J.V.P. and N.C.; writing-review and editing, J.V.P. and N.C.; project administration, N.C.; funding application, N.C. All authors have read and agreed to the published version of the manuscript. 
Funding: This research was conjointly supported by the projects RTI2018-094405-B-100 (co-funded by the Ministerio de Ciencia, Innovación y Universidades and the European Regional Development Fund) and the PsicoSAO-Research Group in Social, Environmental, and Organizational Psychology (2017 SGR 564; Secretaria d'Universitats i Recerca del Departament d'Economia i Coneixement, Generalitat de Catalunya). It also received financial support for publishing from the Vicerectorat de Doctorat i Promoció de la Recerca (Office of the Vice-Rector for Doctoral Studies and Research Promotion), University of Barcelona.

Acknowledgments: The authors express their thanks to Christopher Gladwin for his invaluable help in correcting the English-language manuscript.

Conflicts of Interest: The authors declare no conflict of interest. The funders had no role in the design of the study; in the collection, analyses, or interpretation of data; in the writing of the manuscript, or in the decision to publish the results.

\section{References}

1. Hogg, M.A. Influence and Leadership. In Handbook of Social Psychology; Fiske, S.T., Gilbert, D.T., Lindzey, G., Eds.; John Wiley \& Sons: New York, NY, USA, 2010; Volume 2, pp. 1166-1207.

2. Haslam, S.A.; Reicher, S.D.; Platow, M.J. The new Psychology of Leadership: Identity, Influence and Power; Psychology Press: New York, NY, USA, 2011.

3. Weber, M. The sociology of charismatic authority. In Max Weber: Essays in Sociology; Gerth, H.H., Milles, C.W., Eds.; Oxford University Press: New York, NY, USA, 1946; pp. 245-252, (original work published in 1921).

4. Balmas, M. National Leaders' Personality Cues and Americans' Attitudes toward Their Countries. Int. J. Public Opin. Res. 2019, 31, 694-713. [CrossRef]

5. Judge, T.A.; Bono, J.E.; Ilies, R.; Gerhardt, M.W. Personality and leadership: A qualitative and quantitative review. J. Appl. Psychol. 2002, 87, 765-780. [CrossRef] [PubMed]

6. Nuzulia, S.; Why, F.Y.P. When the Dark Shines: The Role of Dark Personality Traits in Leadership Role Occupancy and Hiring Decisions in a Collectivistic Culture. Soc. Psychol. Pers. Sci. 2020. [CrossRef]

7. Zaccaro, S.J.; Green, J.P.; Dubrow, S.; Kolze, M.J. Leader individual differences, situational parameters, and leadership outcomes: A comprehensive review and integration. Leadersh. Quart. 2018, 29, 2-43. [CrossRef]

8. Montero, M. Teoría y Práctica de la Psicología Comunitaria: La Tensión Entre Comunidad y Sociedad; Paidós: Buenos Aires, Argentina, 2003.

9. Lewin, K.; Lippitt, R. An experimental approach to the study of autocracy and democracy: A preliminary note. Sociometry 1938, 1, 292-300. [CrossRef]

10. Lewin, K.; Lippitt, R.; White, R.K. Patterns of aggressive behaviour in experimentally created "social climates". J. Soc. Psychol. Bull. 1939, 10, 271-299.

11. Fiedler, F. A contingency model of leadership effectiveness. Adv. Exp. Soc. Psychol. 1964, 1, 149-190. [CrossRef]

12. Altmae, S.; Turk, K.; Toomet, O.S. Thomas-Kilmann's Conflict Management Modes and their relationship to Fiedler's Leadership Styles (basing on Estonian organizations). Balt. J. Manag. 2013, 8, 45-65. [CrossRef]

13. Bass, B.M.; Bass, R. The Bass Handbook of Leadership. Theory, Research and Managerial Applications, 4th ed.; The Free Press: New York, NY, USA, 2008.

14. Sun, J.; Chen, X.; Zhang, S. A Review of Research Evidence on the Antecedents of Transformational Leadership. Educ. Sci. 2017, 7, 15. [CrossRef]

15. Hickman, G.R.; Sorenson, G.J. The Power of Invisible Leadership: How a Compelling Common Purpose Inspires Exceptional Leadership; SAGE Publications, Inc.: Thousand Oaks, CA, USA, 2014.

16. Hargreaves, A.; Fink, D. The seven principles of sustainable leadership. Edu. Leaders. 2004, 61(7), 8-13.

17. Yang, J.; Lew, J.Y. Implementing Sustainable Human Resources Practices: Leadership Style Matters. Sustainability 2020, 12, 1794. [CrossRef]

18. Reicher, S.D.; Haslam, S.A.; Platow, M.J. Shared social identity in leadership. Curr. Opin. Psychol. 2018, 23, 129-133. [CrossRef] [PubMed]

19. Turner, J.C.; Chacon-Rivera, M.R. A Theoretical Literature Review on the Social Identity Model of Organizational Leadership. Adv. Dev. Hum. Res. 2019, 21, 371-382. [CrossRef]

20. Burns, H.; Schneider, M. Insights from Alumni: A Grounded Theory Study of a Graduate Program in Sustainability Leadership. Sustainability 2019, 11, 5223. [CrossRef] 
21. Jung, C.G. Archetypes and the Collective Unconscious. In The Collected Works of C. G: Jung; Read, H., Fordham, M., Adler, G., McGuire, W., Eds.; Princeton University Press: New York, NY, USA, 1980; Volume 9/1, (original work published in 1959).

22. Von Franz, M.-L. The Process of Individuation. In Man and His Symbols; Jung, C.G., Ed.; Anchor Press: New York, NY, USA, 1964; pp. 158-229.

23. Jung, C.G. The Structure and Dynamics of the Psyche. In The Collected Works of C. G: Jung; Read, H., Fordham, M., Adler, G., McGuire, W., Eds.; Princeton University Press: New York, NY, USA, 1969; Volume 8, (original work published in 1953).

24. Jung, C.G. Symbols of Transformation. An analysis of the prelude to a case of schizophrenia. In The Collected works of C. G: Jung; Read, H., Fordham, M., Adler, G., McGuire, W., Eds.; Princeton University Press: New York, NY, USA, 1976; Volume 5, (original work published in 1952).

25. Samuels, A. The good-enough leader. In The Vision Thing. Myth, Politics and Psyche in the World; Singer, T., Ed.; Routledge: London, UK, 2000; pp. 34-49.

26. Marston, W.M. Introducing Wonder Woman/Wonder Woman comes to America. In Wonder Woman, a Celebration of 75 Years; DC Comics: Burbank, CA, USA, 2016; pp. 8-30.

27. Mayor, A. The Amazons. Lives and Legends of Warrior Women across the Ancient World; Princeton University Press: Princeton, NJ, USA, 2014.

28. Averett, P. The Search for Wonder Woman. An Autoethnography of Feminist Identity. Affilia 2009, 24, 360-368. [CrossRef]

29. McCausland, E. Wonder Woman, el Feminismo como Superpoder; Errata Naturae: Madrid, Spain, 2017.

30. Jung, C.G. Two Essays in Analytical Psychology. In The Collected Works of C. G: Jung; Read, H., Fordham, M., Adler, G., McGuire, W., Eds.; Princeton University Press: New York, NY, USA, 1976; Volume 7.

31. Jung, C.G. Psychological Types. In The Collected Works of C. G: Jung; Read, H., Fordham, M., Adler, G., McGuire, W., Eds.; Princeton University Press: New York, NY, USA, 1976; Volume 6.

32. Briggs Myers, I. MBTI Inventario Tipológico, Forma G, 3rd ed.; TEA Ediciones, S.A.: Madrid, Spain, 2000.

33. Briggs Myers, I. Introduction to Type. A Guide to Understanding Your Results on the Myer-Briggs Type Indicator, 5th ed.; Consulting Psychologists Press: Palo Alto, CA, USA, 1993.

34. Briggs Myers, I.; McCaulley, M.H. Manual, a Guide to the Development and Use of the Myers-Briggs Type indicator; Consulting Psychologists Press: Palo Alto, CA, USA, 1985.

35. Persky, A.M.; Henry, T.; Campbell, A. An Exploratory Analysis of Personality, Attitudes, and Study Skills on the Learning Curve within a Team-based Learning Environment. Am. J. Pharmaceut. Educ. 2015, 79, 1-20. [CrossRef]

36. Schwartz, S.H.; Melech, G.; Lehman, A.; Burgess, S.; Harris, M.; Owens, V. Extending the cross-cultural validity of the theory of basic human values with a different method of measurement. J. Cross Cult. Psychol. 2001, 32, 519-542. [CrossRef]

37. Gouveia, V.; Milfont, T.L.; Vione, K.C.; Santos, W.S. Guiding actions and expressing needs: On the psychological functions of values. Psykhé 2015, 24, 1-14. [CrossRef]

38. Krishnan, V.R. Value systems of transformational leaders. Leadersh. Org. Dev. J. 2001, 22, 126-132. [CrossRef]

39. Nader, M.; Castro, A. Influencia de los valores sobre los estilos de liderazgo: Un análisis según el modelo de liderazgo transformacional — transaccional de Bass. Univ. Psichol. 2007, 6, 689-698.

40. Nader, M.; Castro, A. Relación entre los estilos de liderazgo, valores y cultura organizacional: Un estudio con líderes civiles y militares. Anu. Psicol. 2009, 40, 237-254.

41. Schwartz, S.H.; Sagie, G. Value consensus and importance: A cross-national study. J. Cross Cult. Psychol. 2000, 31, 465-497. [CrossRef]

42. Sosik, J.J. The Role of Personal Values in the Charismatic Leadership of Corporate Managers: A Model and Preliminary Study. Leadersh. Quart. 2005, 16, 221-244. [CrossRef]

43. Pestana, J.V.; Codina, N. Being Conscious of One's Own Heroism: An Empirical Approach to Analyzing the Leadership Potential of Future CEOs. Front. Psychol. 2019, 9, 278. [CrossRef]

44. Gabriel, Y. Psychoanalytic Approaches to Leadership. In The SAGE Handbook of Leadership; Bryman, A., Collinson, D., Grint, K., Jackson, B., Uhl-Bien, M., Eds.; SAGE: Thousand Oaks, CA, USA, 2011; pp. $393-404$.

45. Allen, S. Leadership and Sustainability. In Encyclopedia of Sustainability in Higher Education; Filho, W., Ed.; Springer Nature: Cham, Switzerland, 2019; pp. 1067-1073. [CrossRef] 
46. Burns, H.L. Learning sustainability leadership: An action research study of a graduate leadership course. IJ-SoTL 2016, 10, 8. [CrossRef]

47. MacVaugh, J.; Norton, M. Introducing Sustainability into Business Education Contexts Using Active Learning. High. Educ. Policy 2011, 24, 439-457. [CrossRef]

48. Segovia-Pérez, M.; Laguna-Sánchez, P.; de la Fuente-Cabrero, C. Education for Sustainable Leadership: Fostering Women's Empowerment at the University Level. Sustainability 2019, 11, 5555. [CrossRef]

49. Israeli, H.; Itamar, S.; Shahar, G. The heroic self under stress: Prospective effects on anxious mood in Israeli adults exposed to missile attacks. J. Res. Pers. 2018, 75, 17-25. [CrossRef]

50. Kinsella, E.L.; Ritchie, T.D.; Igou, E.R. Zeroing in on Heroes: A Prototype Analysis of Hero Features. J. Pers. Soc. Psychol. 2015, 108, 114-127. [CrossRef]

51. Shahar, G. The Heroic Self: Conceptualization, Measurement, and Role in Distress. Int. J. Cogn. Ther. 2013, 6, 248-264. [CrossRef]

52. Allison, S.T.; Goethals, G.R.; Marrinan, A.R.; Parker, O.M.; Spyrou, S.P.; Stein, M. The Metamorphosis of the Hero: Principles, Processes, and Purpose. Front. Psychol. 2019, 10, 606. [CrossRef] [PubMed]

53. Efthimiou, O.; Allison, S.T. Heroism Science: Frameworks for an Emerging Field. J. Humanist. Psychol. 2017. [CrossRef]

54. Kinsella, E.L.; Ritchie, T.D.; Igou, E.R. Lay perspectives on the social and psychological functions of heroes. Fron. Psycho. 2015, 6, 130. [CrossRef] [PubMed]

55. Hoppe, M.H.; Bhagat, R.S. Leadership in the United States of America: The leader a cultural hero. In Culture and Leadership across the World: The GLOBE Book of In-Depth Studies of 25 Societies; Chhokar, J.S., Brodbeck, F.C., House, R.J., Eds.; Lawrence Erlbaum Associates: Mahwah, NJ, USA, 2007; pp. 475-535.

56. Williams, C. The Hero's Journey: A Mudmap to Wellbeing. In Heroism and Wellbeing in the 21st Century. Applied and Emerging Perspectives; Efthimiou, O., Allison, S.T., Franco, Z.E., Eds.; Routledge: New York, NY, USA, 2018; pp. 72-89.

57. Allison, S.T.; Goethals, G.R. Hero worship: The elevation of the human spirit. J. Theor. Soc. Behav. 2015, 46, 187-210. [CrossRef]

58. Nakamura, J.; Graham, L. The Impact of Heroism on Heroes and Observers: Stories of Elevation. In Handbook of Heroism and Heroic Leadership; Allison, S.T., Goethals, G.R., Kramer, R.M., Eds.; Routledge: New York, NY, USA, 2017; pp. 417-437.

59. Kinsella, E.L.; Ritchie, T.D.; Igou, E.R. Attributes and Applications of Heroes: A Brief History of Lay and Academic Perspectives. In Handbook of Heroism and Heroic Leadership; Allison, S.T., Goethals, G.R., Kramer, R.M., Eds.; Routledge: New York, NY, USA, 2017; pp. 19-35.

60. Walker, L.J. The Moral Character of Heroes. In Handbook of Heroism and Heroic Leadership; Allison, S.T., Goethals, G.R., Kramer, R.M., Eds.; Routledge: New York, NY, USA, 2017; pp. 99-119.

61. Jung, C.G. Spirit in Man, Art, and Literature. In The Collected Works of C. G: Jung; Read, H., Fordham, M., Adler, G., McGuire, W., Eds.; Princeton University Press: New York, NY, USA, 1971; Volume 15, (original works published between 1934-1957).

62. Guggenbühl-Craig, A. From the Wrong Side: A Paradoxical Approach to Psychology; Spring Publications: Putna, CT, USA, 2014; (original work published in 1992).

63. Zerbe, K.J. The Phoenix rises from Eros, not ashes: Creative collaboration in the lives of five impressionist and postimpressionist women artists. J. Am. Acad. Psychoanal. 1992, 20, 295-315. [CrossRef]

64. Dowds, B.N. Helping students make connections across disciplines. Creativity. Res. J. 1998, 11, 55-60. [CrossRef]

65. Hollinger, C.L.; Fleming, E.S. Gifted and talented young women: Antecedents and correlates of life satisfaction. Gifted Child 1988, 32, 254-259. [CrossRef]

66. Whiting, J.; Hannam, K. Creativity, self-expression and leisure. Leis. Stud. 2015, 34, 372-384. [CrossRef]

67. American Psychological Association. Creativity. In APA Thesaurus of Psychological Index Terms; Available online: http://web.b.ebscohost.com.sire.ub.edu/ehost/thesaurus?vid=3\&sid=536a83df-9621-45fd9652-2cc51ac916d2\%40pdc-v-sessmgr05 (accessed on 23 April 2020).

68. Amabile, T.M.; Pillemer, J. Perspectives on the Social Psychology of Creativity. J. Creat. Behav. 2012, 46, 3-15. [CrossRef]

69. Runco, M.A. Creativity. Annu. Rev. Psychol. 2004, 55, 657-687. [CrossRef] 
70. Bachtold, L.M.; Werner, E.E. Personality characteristics of creative women. Percept. Mot. Ski. 1973, 36, 311-319. [CrossRef] [PubMed]

71. Helson, R. Personality of women with imaginative and artistic interests: The role of masculinity, originality, and other characteristics in their creativity. J. Personal. 1966, 34, 1-25. [CrossRef] [PubMed]

72. Helson, R. A Longitudinal Study of Creative Personality in Women. Creat. Res. J. 1999, 12, 89-101. [CrossRef]

73. Mundim, M.C.B.; Wechsler, S.M.; Morais, M.F. Environmental and Psychological Factors that Influence the Creative Excellence of Brazilian and Portuguese Women. J. Creat. Behav. 2020. [CrossRef]

74. Vaillant, G.E.; Vaillant, C.O. Determinants and consequences of creativity in a cohort of gifted women. Psychol. Women. Q. 1990, 14, 607-616. [CrossRef]

75. White Bender, S.W.; Nibbelink, B.L.; Towner-Thyrum, E.; Vredenburg, D. Defining Characteristics of Creative Women. Create. Res. J. 2013, 25, 38-47. [CrossRef]

76. Reis, S.M. Toward a Theory of Creativity in Diverse Creative Women. Creat. Res. J. 2002, 14, 305-316. [CrossRef]

77. Burton, L.J. Underrepresentation of women in sport leadership: A review of research. Sport Manag. Rev. 2015, 18, 155-165. [CrossRef]

78. Mullet, D.R.; Rinn, A.N.; Kettler, T. Catalysts of Women's Talent Development in STEM: A Systematic Review. J. Adv. Acad. 2017, 28, 253-289. [CrossRef]

79. Seo, G.; Huang, W.; Han, S.H.C. Conceptual Review of Underrepresentation of Women in Senior Leadership Positions from a Perspective of Gendered Social Status in the Workplace: Implication for HRD Research and Practice. Hum. Resour. De. Re. 2017, 16, 35-59. [CrossRef]

80. Campuzano, M.V. Force and Inertia: A Systematic Review of Women's Leadership in Male-Dominated Organizational Cultures in the United States. Hum. Resour. De. Re. 2019,1-33. [CrossRef]

81. Singh, A.; Sengupta, S.; Sharma, S. Empathy and Mindfulness: Potential Antecedents to Authentic Leadership. Int. J. Hum. Cap. 2016, 4. [CrossRef]

82. Hearing, J.G. Women as leaders in academic institutions: Personal experience and narrative literature review. Pure Appl. Chem. 2019, 91, 331-338. [CrossRef]

83. Stead, V.; Elliot, C. Women's leadership learning: A reflexive review of representations and leadership teaching. Manag. Lear. 2012, 44, 373-394. [CrossRef]

84. Scott, S.S. Dreams and creativity in women. Arts Psychother. 1987, 14, 293-299. [CrossRef]

85. Shinbrot, X.A.; Wilkins, K.; Gretzel, U.; Bowser, G. Unlocking women's sustainability leadership potential: Perceptions of contributions and challenges for women in sustainable development. World De. 2019, 119, 120-132. [CrossRef]

86. Lozano, R.; Lukman, R.; Lozano, F.; Huisingh, D.; Lambrechts, W. Declarations for sustainability in higher education: Becoming better leaders, through addressing the university system. J. Clean. Prod. 2013, 48, 10-19. [CrossRef]

87. Vare, P.; Grete Arro, G.; de Hamer, A.; Del Gobbo, G.; de Vries, G.; Farioli, F.; Kadji-Beltran, C.; Kangur, M.; Mayer, M.; Millican, R.; et al. Devising a Competence-Based Training Program for Educators of Sustainable Development: Lessons Learned. Sustainability 2019, 11, 1890. [CrossRef]

88. Brundiers, K.; Wiek, A. Beyond Interpersonal Competence: Teaching and Learning Professional Skills in Sustainability. Educ. Sci. 2017, 7, 39. [CrossRef]

89. Tractenberg, R.E.; FitzGerald, K.T.; Collmann, J. Evidence of Sustainable Learning from the Mastery Rubric for Ethical Reasoning. Educ. Sci. 2017, 7, 2. [CrossRef]

90. Ato, M.; López, J.J.; Benavente, A. Un sistema de clasificación de los diseños de investigación en psicología. Anales Psicol 2013, 29, 1038-1059. [CrossRef]

91. Codina, N. Aproximación Metodológica a la Complejidad del Self. R. Interam. Psicol. / Interam. J. Psychol. 2004, 38, 13-19.

92. Codina, N. La complejidad del self y análisis empírico de su borrosidad. Enc. Psicol. Soc. 2005, 3, 36-44.

93. Progoff, I. At a Journal Workshop: Writing to Access the Power of the Unconscious and Evoke Creative Ability; Tarcher/Putnam: New York, NY, USA, 1992.

94. Wall, T.; Rossetti, L.; Hopkins, S. Storytelling for Sustainable Development. In Encyclopedia of Sustainability in Higher Education; Filho, W., Ed.; Springer Nature: Cham, Switzerland, 2019; pp. 1532-1539. [CrossRef] 
95. Campbell, J. The Hero with a Thousand Faces; Princeton University Press: Princeton, NJ, USA, 2004; (original work published in 1949).

96. Brown, F.W.; Reilly, M.D. The Myers-Briggs type indicator and transformational leadership. J. Manag. Dev. 2009, 28, 916-932. [CrossRef]

97. Mattare, M. Revisiting Understanding Entrepreneurs Using the Myers-Briggs Type Indicator. J. Mark. Dev. Comp. 2015, 9, 114-119.

98. Mohammadi, S.D.; Rahmatinejad, P.; Seyedtabaee, S.R.; Akbari, V. The Correlation between Early Maladaptive Schemas and Myers-Briggs Personality Dimensions in Medical Students. Qom. Univ. Sci.-Med. J. 2018, 11, 87-94.

99. Kuhn, M.H.; McPartland, T.S. An Empirical Investigation of Self-Attitudes. In Symbolic Interaction: A Reader in Social Psychology, 3rd ed.; Manis, J.G., Meltzer, B.N., Eds.; Allyn and Bacon: Boston, MA, USA, 1967; pp. 83-92, (original work published in 1954).

100. Codina, N. Autodescripción en el TST: Posibilidades y límites. Psicol. Soc. 1998, 10, 23-38.

101. Rees, A.; Nicholson, N. The Twenty Statements Test. In Essential Guide to Qualitative Methods in Organizational Research; Cassel, C., Simon, G., Eds.; Sage: London, UK, 2004; pp. 86-97.

102. Azghari, Y.; Hooghiemstra, E.; Van De Vijver, F.J.R. Young Moroccan-Dutch: Thinking in Dutch, Feeling Moroccan. J. Muslim. Minor. Aff. 2015, 35, 280-295. [CrossRef]

103. Codina, N.; Pestana, J.V.; Stebbins, R.A. Serious and casual leisure activities in the construction of young adult identity: A study based on participants' self-descriptions. OBETS 2017, 12, 65-80. [CrossRef]

104. Escobar, M.; Montes, E.; Sánchez-Sierra, M. Sentido, referencia y atribución en las descripciones personales. Una. Nueva. Perspectiva. Del. TST. Rev. Esp. Sociol. 2015, 24, 25-41.

105. Suslova, O.V. Interpreter professional identity construction in Higher Education. Eur. Proc. Soc. Behav. Sci. 2018, 39, 231-235. [CrossRef]

106. Anderson-Meger, J.; Dixon, P. Teaching Personal Epistemology and Decision Making in a Global Leadership Course. IJTLHE 2019, 31, 310-322.

107. Lozano, R.; Merrill, M.Y.; Sammalisto, K.; Ceulemans, K.; Lozano, F.J. Connecting Competences and Pedagogical Approaches for Sustainable Development in Higher Education: A Literature Review and Framework Proposal. Sustainability 2017, 9, 1889. [CrossRef]

108. Schwartz, S.H. Universals in the Content and Structure of Values: Theory and Empirical Tests in 20 Countries. In Advances in Experimental Social Psychology; Zanna, M., Ed.; Academic Press: New York, NY, USA, 1992; Volume 25, pp. 1-65.

109. Abella García, V.; Lezcano Barbero, F.; Casado Muñoz, R. Evaluación de la jerarquía de los valores humanos de Schwartz en la adolescencia: Diferencias de género e implicaciones educativas. Rev. Bras. Educ. 2017, 22, 123-146. [CrossRef]

110. Schwartz, S.H.; Boehnke, K. Evaluating the structure of human values with confirmatory factor analysis. J. Res. Pers. 2004, 38, 230-255. [CrossRef]

111. Jefatura del Estado (1999, December 14). Ley Orgánica 15/1999, de 13 de diciembre, de Protección de Datos de Carácter Personal. Boletín Oficial del Estado, 298(§23750), 43.088-43. Available online: https://www.boe.es/boe/dias/1999/12/14/pdfs/A43088-43099.pdf (accessed on 20 April 2020).

112. World Medical Association. World Medical Association Declaration of Helsinki: Ethical principles for medical research involving human subjects. JAMA 2013, 310, 2191-2194. [CrossRef]

113. Myers, S. Myers-Briggs Typology and Jungian Individuation. Overcoming One-Sidedness in Self and Society; Routledge: New York, NY, USA, 2019.

114. Davies, B. Sustainable leadership. In Developing Sustainable Leadership; Davies, B., Ed.; Paul Chapman Publishing: London, UK, 2007; pp. 11-27.

115. Briggs Myers, I.; Myers, P.B. Gifts Differing. Understanding Personality Type; Davies-Black Publishing: Mountain View, CA, USA, 1995; (original work published in 1980).

116. Wall, T.; Österlind, E.; Fries, J. Arts-Based Approaches for Sustainability. In Encyclopedia of Sustainability in Higher Education; Filho, W., Ed.; Springer Nature: Cham, Switzerland, 2019; pp. 50-56. [CrossRef]

117. Gough, S.; Scott, W. Higher Education and Sustainable Development. Paradox and Possibility; Routledge: New York, NY, USA, 2008. 
118. Zoller, U. Research-Based Transformative Science/STEM/STES/STESEP Education for "Sustainability Thinking": From Teaching to "Know" to Learning to "Think". Sustainability 2015, 7, 4474-4491. [CrossRef]

119. Hull, R.B.; M Mortimer, M.; Robertson, D. Developing Cosmopolitan Competencies in Sustainability Professionals. IJTLHE 2019, 31, 346-353.

120. Rovio-Johansson, A. Students' Knowledge Progression: Sustainable Learning in Higher Education. IJTLHE 2016, 28, 427-439.

121. Sammalisto, K.; Sundström, A.; von Haartman, R.; Holm, T.; Yao, Z. Learning about Sustainability-What Influences Students' Self-Perceived Sustainability Actions after Undergraduate Education? Sustainability 2016, 8, 510. [CrossRef]

(C) 2020 by the authors. Licensee MDPI, Basel, Switzerland. This article is an open access article distributed under the terms and conditions of the Creative Commons Attribution (CC BY) license (http://creativecommons.org/licenses/by/4.0/). 